\title{
Using a State-of-the-art Air Pollution Control System to Lower Pollutant Emissions
}

\author{
Yi-Ming Kuo ${ }^{1,2^{*}}$, Jhong-Lin $\mathrm{Wu}^{3 * *}$, Sheng-Lun $\operatorname{Lin}^{4,5,6^{* * * *}}$ \\ ${ }^{1}$ Department of Safety Health and Environmental Engineering, Chung Hwa University of Medical Technology, Tainan \\ 71703, Taiwan \\ 2 Department of Optometry, Chung Hwa University of Medical Technology, Tainan 71703, Taiwan \\ ${ }^{3}$ Environmental Resource Management Research Center, National Cheng Kung University, Tainan 70955, Taiwan \\ ${ }^{4}$ Department of Civil Engineering and Geomatics, Cheng Shiu University, Kaohsiung 83347, Taiwan \\ ${ }^{5}$ Center for Environmental Toxin and Emerging-Contaminant Research, Cheng Shiu University, Kaohsiung 83347, \\ Taiwan \\ ${ }^{6}$ Super Micro Mass Research and Technology Center, Cheng Shiu University, Kaohsiung 83347, Taiwan
}

\begin{abstract}
This study focused on the pollutant characteristics of a renovated laboratory waste treatment plant that adopted a state-ofthe-art design for its air pollution control system. The output materials, including slag, primary quenching tower ash, scrubbing wastewater, sludge, fabric filter ash, and flue gas, were sampled and analyzed. Incorporating an organic liquid waste injector into the primary combustion chamber enabled the local temperature to be increased to approximately 1300 $1400^{\circ} \mathrm{C}$, thereby reducing the PCDD/F concentration in the slag to $0.019 \mathrm{ng} \mathrm{I}^{\mathrm{T}} \mathrm{TEQ} \mathrm{g}{ }^{-1}$ and the PCDD/F emission factor to $699 \mu \mathrm{g}$ I-TEQ ton-waste ${ }^{-1}$. In addition, the concentration of the flue gas was much lower than the regulated standard, and the low level of emissions contributed to the performance of the air pollution control devices. The fly ash contained crystalline-phase $\mathrm{NaCl}$ or other sodium salts that resulted from the neutralization of $\mathrm{NaOH}$ by acidic pollutants. However, high concentrations of $\mathrm{Cl}$ and $\mathrm{PCDD} /$ Fs were measured in the scrubbing wastewater and sludge, respectively. The scrubbing unit of the renovated air pollution control system was placed in front of the fabric filter to remove $\mathrm{HCl}$, thus providing excellent protection for the filter.
\end{abstract}

Keywords: Air pollution control devices; Fly ash; Incinerator; Laboratory waste.

\section{INTRODUCTION}

To treat the laboratory waste (LW) generated during research and education in schools, in 2005, the Ministry of Education subsidized the Sustainable Environment Research Center (SERC) at National Cheng Kung University to build a treatment plant located in Tainan City to dispose of LW (Wu et al., 2014a). This LW treatment plant has three major systems: a physicochemical treatment system, an incineration

\footnotetext{
* Corresponding author.

Tel.: +886-6-2674567 ext. 854; Fax: +886-6-2675049

E-mail address: kuoyiming@gmail.com

** Corresponding author.

Tel.: +886-6-384-0136 ext. 230; Fax: +886-6-384-0143

E-mail address: z8406004@email.ncku.edu.tw

*** Corresponding author.

Tel.: +886-7-735-8800 ext. 2605; Fax: +886-7-733-2204

E-mail address: cbmsgml@gmail.com
}

system, and a plasma melting system. Among these systems, the incineration system was assigned to treat combustible LW and plastic containers. The plastic containers were composed of polyethylene, polypropylene, or plastic materials. The combustible LW included medical or biochemical experiments, which usually had high levels of $\mathrm{Cl}$ (Coutinho et al., 2006).

Previous studies have shown that a large amount of polychlorinated dibenzo- $p$-dioxins and dibenzofurans (PCDD/Fs) or polycyclic aromatic hydrocarbons (PAHs) are generated when waste with high levels of $\mathrm{Cl}$ is incinerated (Wang and Chang-Chien, 2007; Wang et al., 2010; Liao et al., 2014). It has been reported that the PCDD/Fs and PAHs are harmful to public health, and thus the flue gas and ashes needed further treatment to avoid secondary pollution (Hung et al., 2018; Liu et al., 2019a). However, even with appropriate treatment using air pollution control devices (APCDs), the $\mathrm{PCDD} / \mathrm{F}$ content in fly ashes is still extremely high and requires final disposal to avoid threatening public health (Hsieh et al., 2018). Plasma melting systems are set up to dispose of hazardous residues, including sludge and toxic ashes or other wastes from incineration and physicochemical 
systems (Kuo et al., 2010). After the thermal melting process, hazardous materials are transformed into amorphous, stable slag that can be recycled and remade into composites with polyester resin (Kuo et al., 2003, 2011).

In addition to the formation of high level of $\mathrm{PCDD} / \mathrm{Fs}$, the $\mathrm{Cl}$ in input materials caused another problem: It is transformed into $\mathrm{HCl}$ during the incineration process. This acid gas seriously corrodes the components of the system. After a decade of operation, the incineration system will be worn out and require renovation. Therefore, the APCD process was newly designed following a state-of-the-art concept to eliminate the corrosion due to the presence of $\mathrm{HCl}$.

This study focused on the emission characteristics and the distribution of pollutants over the entire incineration process. The $\mathrm{PCDD} / \mathrm{F}$ and $\mathrm{HCl}$ concentrations in output materials were analyzed to determine their mass distributions among the output materials. The crystalline characteristics and surface structure of solid specimens were investigated. In addition, the operating characteristics of the old and renovated incineration systems were compared and discussed.

\section{METHODS}

\section{Processes in the Old and Renovated Incineration Systems}

The process flow diagram of the old incineration system is shown in Fig. 1. The LW was fed with $375 \mathrm{~kg} \mathrm{~h}^{-1}$ through a feeding unit into the primary combustion chamber, and the incineration temperature was maintained above $900^{\circ} \mathrm{C}$. The bottom ash was quenched using water and collected in the ash pit. The flue gas was heated to $1150^{\circ} \mathrm{C}$ by a diesel combustor in the secondary combustion chamber to destroy any unburned residues, $\mathrm{CO}$, and persistent organics, and then the flue gas passed through a series of APCDs.

The primary and secondary quenching towers quenched the flue gas rapidly to $400^{\circ} \mathrm{C}$ and $160^{\circ} \mathrm{C}$, respectively, in order to reduce the formation of $\mathrm{PCDD} / \mathrm{Fs}$. The activated carbon was injected into the flue gas to adsorb the PCDD/Fs and was trapped with residual particulate by the fabric filter. After passing through the fabric filter, a wet scrubber was used to remove residual $\mathrm{HCl}$ to protect the induced-draft fan. Without this unit, the induced-draft fan would be broken within two weeks. The flue gas was heated to $110^{\circ} \mathrm{C}$ before being emitted into the ambient air to avoid the formation of white mist. The pollutant emission characteristics of this incineration system have been reported in previous studies (Chang et al., 2012; Wu et al., 2014b).

Fig. 2 shows the process flow diagram of the renovated system. An organic liquid waste injector was integrated with the primary combustion chamber to generate a local high temperature (ranging from approximately $1300-1400^{\circ} \mathrm{C}$ ) to melt the burned materials and bottom ash. The melted material was then quenched to form inert slag and was collected in the pit. The extra heat also elevated the temperature of the flue gas and reduced the concentration of particulates and PCDD/Fs (Tsai et al., 2018). Similar to the old incineration system, the flue gas was heated to $1150^{\circ} \mathrm{C}$ and then quenched to $400^{\circ} \mathrm{C}$. After the primary quenching tower, the flue gas was directly quenched using a Venturi scrubber and wet scrubber to $60^{\circ} \mathrm{C}$ to remove the particulates 


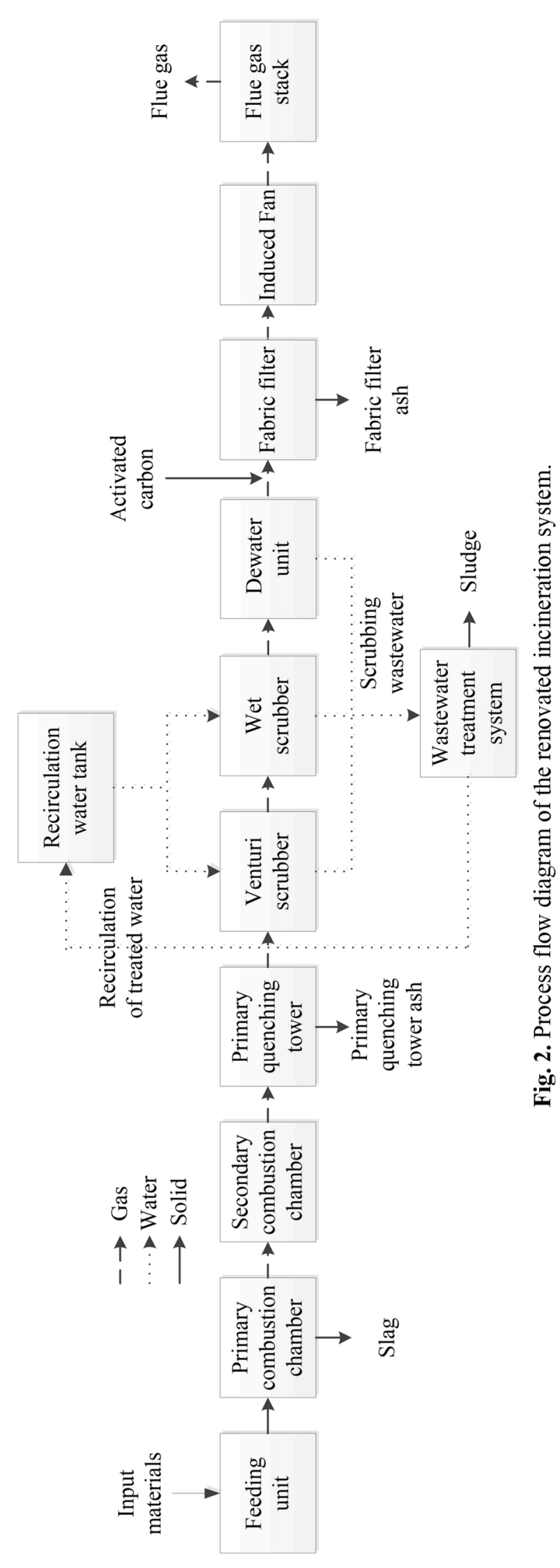

and $\mathrm{HCl}$. The wastewater was treated using a wastewater treatment system, and the pollutants were removed from the wastewater as sludge. The treated wastewater was stored in a tank and recirculated into the two scrubbers to save water. The flue gas then passed through a dewatering unit to remove moisture to avoid clogging the fabric filter. The activated carbon was injected into the flue gas and filtrated using the fabric filter, and the flue gas was emitted into the ambient air. The primary quenching tower ash, sludge, and fabric filter ash were further treated using the plasma melting system to form inner slag.

\section{Determination of Pollutants from Stack}

The incineration tests were conducted in triplicate. The feeding materials were mainly LW, and the $\mathrm{Cl}$ level was estimated to be as high as $10 \%$. The slag, ashes, scrubbing wastewater, sludge, and flue gas were all sampled and analyzed to evaluate the performance of the renovated incineration system. The pollutant concentrations from the stack, including $\mathrm{SO}_{2}, \mathrm{NO}_{x}, \mathrm{O}_{2}, \mathrm{CO}, \mathrm{HCl}$, particulate, $\mathrm{PCDD} / \mathrm{Fs}$, and heavy metals, were determined in this study. The sampling and analysis procedure all followed the standard method established by the Taiwan Environmental Protection Administration (TEPA). A gas analyzer (PG-250A; Horiba) was used to measure the $\mathrm{NO}_{x}$ concentration via a chemiluminescence detection method (TEPA, 2006a), the concentrations of $\mathrm{SO}_{2}, \mathrm{CO}_{2}$, and $\mathrm{CO}$ were obtained via nondispersive infrared absorption (TEPA, 2006b, c, 2016), and the $\mathrm{O}_{2}$ concentration was obtained via the galvanic cell method (TEPA, 2006d). The HCl concentration of the flue gas was determined using a mercury(II) thiocyanate colorimetric method (TEPA, 2008). The detailed procedure for measuring these gases is given in the corresponding methods (TEPA, 2006a, b, c, d, 2008, 2016).

For the analysis of the particulate and heavy metals $(\mathrm{Cd}$, $\mathrm{Hg}$, and $\mathrm{Pb}$ ), the flue gas sampler, equipped with a filter holder, a cooling device, a pump, and a flow meter, was used to isokinetically sample at an average flow rate of $3 \mathrm{~L} \mathrm{~min}^{-1}$. The sampling procedure followed the TEPA standard method (TEPA, 2005, 2006e) and were given in our previous work (Kuo et al., 2004). For the PCDD/Fs, the sampling train for the flue gas met the TEPA A807.75C requirements (TEPA, 2010). Before sampling, the probe was washed with acetone, dichloromethane, and toluene, in that order.

A cartridge was filled with 20-40 g adsorbent (Amberlite $\mathrm{XD}-2^{\circledR}$ ) and was spiked with five PCDD/F surrogate standards pre-labeled with isotopes, ${ }^{37} \mathrm{Cl}_{4}-2,3,7,8$-TCDD, ${ }^{13} \mathrm{C}_{12}-1,2,3,4,7,8-\mathrm{HxCDD},{ }^{13} \mathrm{C}_{12}-2,3,4,7,8-\mathrm{PeCDF},{ }^{13} \mathrm{C}_{12}$ $1,2,3,4,7,8-\mathrm{HxCDF}$, and ${ }^{13} \mathrm{C}_{12}-1,2,3,4,7,8,9-\mathrm{HpCDF}$. The flue gas was sampled isokinetically, and the samples were preserved and transported to the laboratory at $10^{\circ} \mathrm{C}$ for further analysis.

The samples were initially spiked with the ${ }^{13} \mathrm{C}_{12}$-labeled internal standard. A series of steps, including a Soxhlet extraction for $24 \mathrm{~h}$, measurement of the nitrogen blowing concentration, the cleanup and fractionation procedure, and measurement of the nitrogen blowing re-concentration, were conducted to pretreat the samples. The final concentrated eluate (about $1 \mathrm{~mL}$ ) was analyzed using a high-resolution 
gas chromatograph (HRGC; 6970 Series gas; Hewlett-Packard, CA, USA) and a high-resolution mass spectrometer (HRMS; Micromass AutoSpec Ultima; Waters, Manchester, UK) to determine the concentration of the PCDD/Fs. The PCDD/F analysis followed the standard methods announced in TEPA NIEA A808.75B. The methods and details of the procedure followed a previous study (TEPA, 2013; Chen et al., 2018).

\section{Sampling and Analysis of Wastewater and Solid Specimens}

Output materials, including the slag, primary quenching tower ash, scrubbing wastewater, sludge, and fabric filter ash, were collected from the bottom ash pit and air pollution control devices of the incineration systems. The solid specimens were dried, pulverized, and ground to a particle size that could pass through a mesh with a pore size of $149 \mu \mathrm{m}$ to ensure homogeneity. The ground powder was pretreated and analyzed following the above-mentioned method for the PCDD/F analysis. For the analysis of metals, the digestion procedure, which was modified from the standard method provided in NIEA R317.11C (TEPA, 2004), was conducted to pretreat the solid specimens. Ground samples $(\sim 0.1 \mathrm{~g})$ were placed in Teflon tubes to which $2 \mathrm{~mL} \mathrm{HCl}$ $(32 \mathrm{wt} \%)$ and $4 \mathrm{~mL} \mathrm{HNO}_{3}(67 \mathrm{wt} \%)$ were added. The Teflon tubes were sealed and heated using a microwave digester (MARSXpress; CEM) with the following program: heated to $200^{\circ} \mathrm{C}$ at a rate of $4^{\circ} \mathrm{C} \mathrm{min}{ }^{-1}$, held isothermally for $30 \mathrm{~min}$, and cooled down with induced ventilation. The digested solutions were diluted with deionized water to $50 \mathrm{~mL}$. Before the analysis of the metal concentration, the wastewater and diluted solutions were filtrated using mixed cellulose ester filters (pore size $=0.8 \mu \mathrm{m}$ ) to remove any suspended solids. The metal concentrations, including $\mathrm{Cd}, \mathrm{Cr}, \mathrm{Cu}, \mathrm{Fe}, \mathrm{K}, \mathrm{Mn}$, $\mathrm{Na}, \mathrm{Ni}, \mathrm{Pb}$, and $\mathrm{Zn}$, in the solutions were measured using atomic absorption spectroscopy (AAS; 50AA; Agilent Technologies).

\section{Crystalline Characteristics and Surface Microstructure of the Solid Specimens}

In order to analyze the crystalline phases and surface microstructure, the powdered samples were further ground to a particle size smaller than $74 \mathrm{~mm}$ (passing through a \#200 mesh). An X-ray diffraction analysis was conducted using an
X-ray diffractometer (D8; Bruker) to determine the crystalline phases of the solid specimens. The operating parameters included a current of $10 \mathrm{~mA}$, a voltage of $40 \mathrm{kV}$, a scan range of $2 \theta$ between $20^{\circ}$ and $80^{\circ}$, and a scan rate of $4^{\circ} \mathrm{min}^{-1}$. The crystalline phases of the specimens were determined through a comparison with the XRD patterns obtained from the International Center for Diffraction Data (ICDD).

The powdered specimens were adhered onto a metallic plate and coated with a film of Au. Scanning electron microscopy (SEM; JXA-840; JEOL) with an accelerating voltage ranging from 0.5 to $30 \mathrm{kV}$ was used to examine the surface microstructure of the solid specimens with a 10,000fold magnification factor.

\section{RESULTS AND DISCUSSION}

\section{Pollution Characteristics of the Output Material}

Table 1 shows the characteristics of the pollutant emissions from the flue gas. The $\mathrm{O}_{2}, \mathrm{CO}_{2}$, and $\mathrm{CO}$ concentrations in the flue gas were $15.7 \%, 4.2 \%$, and 14 ppm, respectively. Based on the $\mathrm{CO}_{2}$ and $\mathrm{CO}$ concentrations, the combustion efficiency $\left(=\left[\mathrm{CO}_{2}\right] /\left(\left[\mathrm{CO}_{2}\right]+[\mathrm{CO}]\right) \times 100 \%\right)$ was $99.97 \%$. The results show that the combustion behavior in the primary and secondary combustion chamber occurred under oxygen-rich conditions, and the LW could be effectively decomposed (Aurell and Marklund, 2009; Kuo et al., 2019). The $\mathrm{NO}_{x}$ concentration was $76.5 \mathrm{ppm}$, which was slightly higher than that in the old system and was nearly half the regulated concentration in the emission standard. This was probably due to the thermal $\mathrm{NO}_{x}$ caused by the local high temperature $\left(\sim 1300^{\circ} \mathrm{C}\right)$ in the primary combustion chamber. In addition, the main objective of the renovated APCD system was not to remove $\mathrm{NO}_{x}$. If confronted with a stringent $\mathrm{NO}_{x}$ regulation, a unit of activated carbon adsorption or selective catalytic reduction could be integrated into the proposed system to reduce the $\mathrm{NO}_{x}$ concentration (Fang et al., 2019; Liu et al., 2019b).

The $\mathrm{Cl}$ level of the input materials was estimated to be $10 \%$ or even higher, where, according to previous reports, the incineration process generates a huge amount of $\mathrm{HCl}$ and PCDD/Fs (Hatanaka et al., 2005). However, the concentrations of $\mathrm{SO}_{2}, \mathrm{HCl}$, and PCDD/Fs were only $6.5 \mathrm{ppm}, 0.775 \mathrm{ppm}$,

Table 1. Emission characteristics of the flue gas.

\begin{tabular}{llll}
\hline Item & Average & RSD (\%) & Regulated standard $^{*}$ \\
\hline $\mathrm{O}_{2}(\%)$ & 15.7 & 4.1 & - \\
$\mathrm{CO}_{2}(\%)$ & 4.2 & 6.7 & - \\
$\mathrm{CO}(\mathrm{ppm})$ & 14 & 20.2 & 220 \\
$\mathrm{NO}_{x}(\mathrm{ppm})$ & 76.5 & 82.3 & 180 \\
$\mathrm{SO}_{2}(\mathrm{ppm})$ & 6.5 & 10.9 & 180 \\
$\mathrm{HCl}(\mathrm{ppm})$ & 0.775 & 22.8 & 60 \\
$\mathrm{Particulate}\left(\mathrm{mg} \mathrm{Nm}^{-3}\right)$ & 1.05 & 6.7 & 180 \\
$\left.\mathrm{PCDD} / \mathrm{Fs}^{-3} \mathrm{~g} \mathrm{I}_{\mathrm{TEQ} \mathrm{Nm}}{ }^{-3}\right)$ & 0.109 & 42.1 & 0.5 \\
$\mathrm{Cd}(\mathrm{mg} \mathrm{Nm}$ & & 2.2 & 0.04 \\
$\mathrm{Hg}\left(\mathrm{mg} \mathrm{Nm}^{-3}\right)$ & 0.0019 & 5.2 & 0.1 \\
$\mathrm{~Pb}\left(\mathrm{mg} \mathrm{Nm}^{-3}\right)$ & 0.0014 & 36.4 & 0.5 \\
\hline $\mathrm{RSD}(\mathrm{rative}$ & 0.0123 & & \\
\hline
\end{tabular}

RSD (relative standard deviation $)=($ standard deviation/average $) \times 100 \%$.

${ }^{*}$ TEPA $(2003,2006 f)$. 
and $0.109 \mu \mathrm{g} \mathrm{I-TEQ} \mathrm{Nm}^{-3}$, respectively, which were all much lower than the regulated standard (TEPA, 2003). In addition, the concentrations of particulate and heavy metals were near the detection limits. The results showed that the APCDs effectively reduced the pollutant emissions.

Table 2 shows the metal content, PCDD/Fs, and $\mathrm{Cl}$ in the output materials. In the primary combustion chamber, the LW was incinerated and melted into slag. The levels of PCDD/Fs and Cl were $0.019 \mathrm{ng} \mathrm{I-TEQ} \mathrm{g}{ }^{-1}$ and $1080 \mathrm{mg} \mathrm{kg}^{-1}$, respectively, which were much lower than those of the old incineration system (1.87 $\mathrm{ng}$ I-TEQ $\mathrm{g}^{-1}$ and $105,000 \mathrm{mg} \mathrm{kg}^{-1}$; Wu et al., 2014b). This could be explained by the fact that the local high temperature destroyed the PCDD/Fs and caused more $\mathrm{Cl}$ to vaporize into the flue gas. The slag also had $\mathrm{Fe}$ (6390 $\left.\mathrm{mg} \mathrm{kg}^{-1}\right), \mathrm{Cu}\left(2610 \mathrm{mg} \mathrm{kg}^{-1}\right)$, and $\mathrm{Mn}\left(2570 \mathrm{mg} \mathrm{kg}^{-1}\right)$, and other metals were in trace amounts.

The primary quenching tower ash was mainly composed of $\mathrm{Na}\left(202,000 \mathrm{mg} \mathrm{kg}^{-1}\right)$ and $\mathrm{Cl}\left(312,000 \mathrm{mg} \mathrm{kg}^{-1}\right)$, which came from the reaction (as shown in Eq. (1)) of the $\mathrm{NaOH}$ solution injected with the $\mathrm{HCl}$ in the flue gas. Except for $\mathrm{K}$ $\left(32,600 \mathrm{mg} \mathrm{kg}^{-1}\right)$, there were very small amounts of other metals in the primary quenching tower ash.

$\mathrm{NaOH}+\mathrm{HCl} \rightarrow \mathrm{NaCl}+\mathrm{H}_{2} \mathrm{O}$

The PCDD/F level in the primary quenching tower ash was

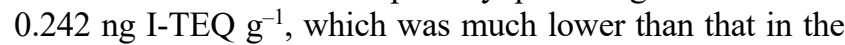
municipal solid waste incinerator (Lin et al., 2008). The solution of $40 \% \mathrm{NaOH}$ was used as the scrubbing water, and, thus, the wastewater had high levels of $\mathrm{Na}^{+}\left(174,000 \mathrm{mg} \mathrm{L}^{-1}\right)$. Due to the circulation of the scrubbing wastewater, the $\mathrm{Cl}^{-}$ gradually accumulated to as high as $52,000 \mathrm{mg} \mathrm{L}^{-1}$. In addition, due to the vaporization of water and neutralization of acid gas, it was necessary to refill the $\mathrm{NaOH}$ solution to maintain the alkalinity of the recirculated wastewater and the water level. A previous study reported that scrubbers could effectively remove PCDD/Fs (Lee et al., 2004). Therefore, similar to $\mathrm{HCl}$, the $\mathrm{PCDD} / \mathrm{Fs}$ also accumulated in the recirculation units, and thus, the $\mathrm{PCDD} / \mathrm{F}$ concentration in the wastewater was as high as $10,900 \mathrm{pg} \mathrm{L}^{-1}$. On the other hand, the suspended solids in the scrubbing wastewater were removed by the wastewater treatment system and collected as sludge. Due to low vapor pressure and solubility, the PCDD/Fs in the flue gas mainly existed in the particulate phase. The particulate phase was scrubbed out from the flue gas, and the PCDD/Fs were highly concentrated in the suspended solids. Therefore, the PCDD/F levels were as high as $83.5 \mu \mathrm{g} \mathrm{I-TEQ} \mathrm{g}^{-1}$. In addition, the sludge had Mn $\left(29,500 \mathrm{mg} \mathrm{kg}^{-1}\right)$, Fe $\left(21,300 \mathrm{mg} \mathrm{kg}^{-1}\right)$, $\mathrm{Na}\left(9700 \mathrm{mg} \mathrm{kg}^{-1}\right)$, and $\mathrm{Cl}\left(7460 \mathrm{mg} \mathrm{kg}^{-1}\right)$. After passing through the scrubbing unit, the activated carbon and residual particulates were trapped as fabric filter ash. The fabric filter ash had $\mathrm{Cl}$ (38,000 mg kg-1), Na (24,100 mg kg-1), Fe (5340 mg kg-1), and $\mathrm{K}$ (3240 $\left.\mathrm{mg} \mathrm{kg}^{-1}\right)$, and the PCDD/F level was $1.14 \mu \mathrm{g} \mathrm{I}$ TEQ $\mathrm{g}^{-1}$.

Fig. 3 shows the PCDD/F patterns of the output materials. The major three $\mathrm{PCDD} / \mathrm{F}$ congeners in the ingot were 2,3,4,7,8-PeCDF (47.9\%), OCDF (25.6\%), and 2,3,7,8TeCDF (16.5\%). The PCDD/F flue gas profile was similar to those of the other output materials. The PCDD/F mass of these output materials was mainly distributed in $2,3,7,8$ TeCDF ( 20\%). Next to 2,3,7,8-TeCDF, the other congeners, including 1,2,3,7,8-PeCDD (9.94\%), 1,2,3,4,7,8-HxCDD (12.2\%), 1,2,3,6,7,8-HxCDD (10.2\%), 1,2,3,7,8,9-HxCDD (9.5\%), and OCDF (9.3\%), all accounted for about $10 \%$.

\section{Mass Distribution of PCDD/Fs and HCl among Output Materials}

Table 3 shows the mass distribution of PCDD/Fs and $\mathrm{HCl}$ among the output materials in the two incineration systems. Due to the local high temperature in the primary combustion chamber, the mass fractions of PCDD/Fs and $\mathrm{Cl}$ in the slag were only $0.04 \%$ and $0.01 \%$, respectively, which were much lower than those in the bottom ash in the old incineration system $(31.6 \%$ and $24.9 \%)$. For the renovated incineration system, the PCDD/F mass (97.02\%) mainly existed in the scrubbing units and the loading in the fabric filter for $\mathrm{PCDD} / \mathrm{F}$ removal was much lighter than that in the other systems (Wang and Chang-Chien, 2007; Wang et al., 2010). The mass fraction of PCDD/Fs emitted from the flue gas was only $0.23 \%$, indicating good performance of this APCD in terms of the removal of PCDD/Fs.

For the renovated incineration system, the $\mathrm{Cl}$ mass fraction removed by the primary quenching tower was only $10.3 \%$,

Table 2. Metals, $\mathrm{PCDD} / \mathrm{F}$, and $\mathrm{Cl}$ content in the output materials.

\begin{tabular}{|c|c|c|c|c|c|}
\hline & Slag $\left(\mathrm{mg} \mathrm{kg}^{-1}\right)$ & $\begin{array}{l}\text { Primary quenched } \\
\text { tower ash }\left(\mathrm{mg} \mathrm{kg}^{-1}\right)\end{array}$ & Sludge (mg kg-1) & $\begin{array}{l}\text { Scrubbing wastewater } \\
\left(\mathrm{mg} \mathrm{L}^{-1}\right)\end{array}$ & $\begin{array}{l}\text { Fabric filter ash } \\
\left(\mathrm{mg} \mathrm{kg}^{-1}\right)\end{array}$ \\
\hline $\mathrm{Cd}$ & N.D. & 24.2 & 248 & 0.15 & 17.6 \\
\hline $\mathrm{Cr}$ & 207 & N.D. & 133 & 0.24 & 96.6 \\
\hline $\mathrm{Cu}$ & 2610 & 356 & 884 & 5.74 & 391 \\
\hline $\mathrm{Fe}$ & 6390 & 572 & 21,300 & 4.93 & 5340 \\
\hline $\mathrm{K}$ & 363 & 32,600 & 1070 & 241 & 3240 \\
\hline Mn & 2570 & N.D. & 29,500 & 0.19 & 292 \\
\hline $\mathrm{Na}$ & 161 & 202,000 & 9700 & 174,000 & 24,100 \\
\hline $\mathrm{Ni}$ & 920 & 77.4 & 364 & 1.05 & 82.9 \\
\hline $\mathrm{Pb}$ & 193 & 252 & 810 & 4.29 & 199 \\
\hline $\mathrm{Zn}$ & 127 & 448 & 3480 & 8.10 & 620 \\
\hline $\mathrm{PCDD} / \mathrm{Fs}$ & $0.019 \mathrm{ng} \mathrm{I}^{-T E Q} \mathrm{~g}^{-1}$ & $0.242 \mathrm{ng}$ I-TEQ $\mathrm{g}^{-1}$ & 83.5 ng I-TEQ $\mathrm{g}^{-1}$ & 10,900 pg I-TEQ L ${ }^{-1}$ & $1.14 \mathrm{ng}$ I-TEQ $\mathrm{g}^{-1}$ \\
\hline $\mathrm{Cl}$ & 1079 & 312,000 & 7460 & 52,000 & 38,000 \\
\hline
\end{tabular}



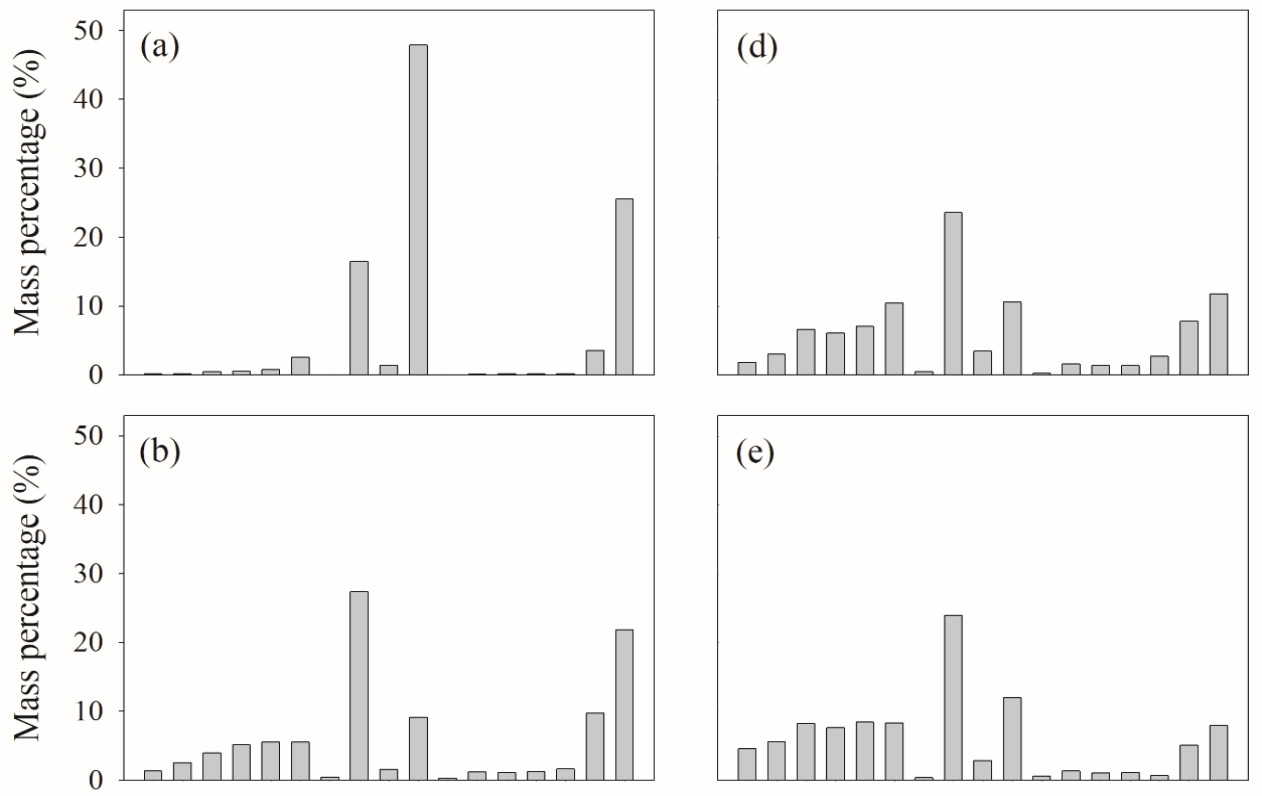

(e)
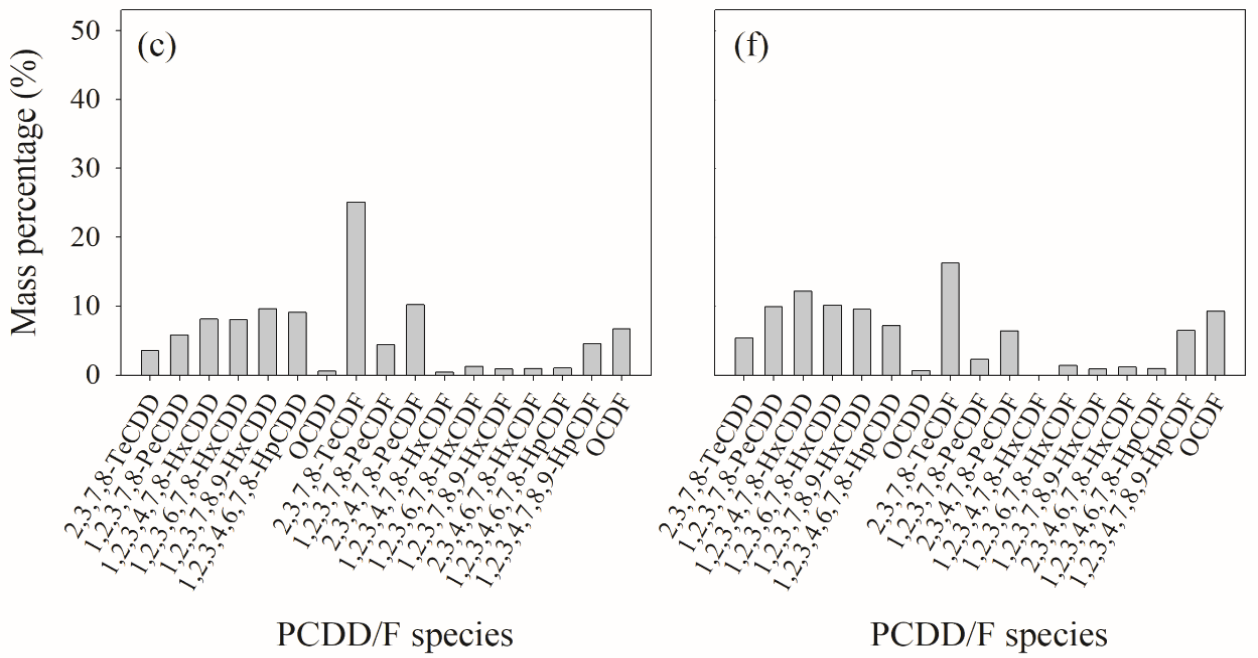

Fig. 3. PCDD/F patterns of output materials: (a) slag, (b) primary quenching tower ash, (c) scrubbing wastewater, (d) sludge, (e) fabric filter ash, (f) flue gas.

Table 3. Mass percentage of $\mathrm{PCDD} / \mathrm{Fs}$ and $\mathrm{Cl}$ in the output materials in the renovated and old incineration systems.

\begin{tabular}{|c|c|c|c|c|c|c|c|}
\hline & Item & Slag & $\begin{array}{l}\text { Primary } \\
\text { quenching } \\
\text { tower ash }\end{array}$ & Sludge & $\begin{array}{l}\text { Scrubbing } \\
\text { wastewater }\end{array}$ & $\begin{array}{l}\text { Fabric filter } \\
\text { ash }\end{array}$ & Flue gas \\
\hline \multirow[t]{3}{*}{ Renovated system } & PCDD/Fs & 0.04 & 1.66 & 92.97 & 4.05 & 1.06 & 0.23 \\
\hline & $\mathrm{Cl}$ & 0.01 & 10.30 & 0.05 & 89.38 & 0.17 & 0.08 \\
\hline & Item & Bottom ash & $\begin{array}{l}\text { Primary } \\
\text { quenching } \\
\text { tower ash }\end{array}$ & $\begin{array}{l}\text { Secondary } \\
\text { quenching } \\
\text { tower ash }\end{array}$ & $\begin{array}{l}\text { Fabric filter } \\
\text { ash }\end{array}$ & $\begin{array}{l}\text { Wet scrubber } \\
\text { ash }\end{array}$ & Flue gas \\
\hline \multirow[t]{2}{*}{ Old system } & PCDD/Fs & 31.6 & 28.7 & 1.75 & 32.6 & 1.8 & 3.52 \\
\hline & $\mathrm{Cl}$ & 24.9 & 20.1 & 4.99 & 19.9 & 31.0 & 0.17 \\
\hline
\end{tabular}

and, thus, the $\mathrm{Cl}$ mass existing in the flue gas was still as much as $89.7 \%$. The Venturi and wet scrubbers removed $89.4 \%$ of the $\mathrm{Cl}$ mass, and the $\mathrm{Cl}$ mass fraction reaching the fabric filter was greatly reduced to $0.25 \%$. This prevented the fabric filter from being corroded by $\mathrm{HCl}$. When it came to the old incineration system, the mass fraction of $\mathrm{HCl}$ removed by two quenching towers was only $25.09 \%$, and thus, the fabric filter still had to process an $\mathrm{HCl}$ mass of $51.07 \%$. Therefore, the welding bead and the plate edge of the components in the fabric filter were seriously corroded 
and had to be repaired at least once a year. After the fabric filter, the wet scrubber removed $31.0 \%$ of the $\mathrm{Cl}$ mass, which explained why the induced-draft fan broke in two weeks without the wet scrubber.

\section{Surface Microstructure and Crystalline Phase of the Solid Specimens}

Figs. 4 and 5 show the SEM images and XRD patterns of the solid specimens. Due to being melted, the structure of the slag was bulky and rigid and had flat, sharp-edged surfaces, which was completely different from the other ashes and sludge. The major crystalline phase in the slag was $\mathrm{Ca}_{5}\left(\mathrm{SiO}_{4}\right)_{2}\left(\mathrm{SO}_{4}\right)$ (ternesite) and $\mathrm{Ca}_{10}\left(\mathrm{SiO}_{4}\right)_{3}\left(\mathrm{SO}_{4}\right)_{3}(\mathrm{OH}, \mathrm{F}$, $\mathrm{Cl})_{2}$ (hydroxylellestadite), which were mainly composed of igneous rock and neutralized salts. These crystalline phases are often found in high-temperature environments, which was consistent with the conditions in the primary combustion chamber (melting and then quenching).

The crystalline phases in the primary quenching tower ash mainly comprised $\mathrm{NaCl}$ with some $\mathrm{Na}_{4}\left(\mathrm{SO}_{4}\right)_{2} \cdot \mathrm{NaCl} \cdot \mathrm{NaF}$ (sulfohalite), which were all salts due to the neutralization of $\mathrm{NaOH}$ with acid pollutants. The primary quenching tower ash had a powdery, porous structure, which mainly came from the aggregation of $\mathrm{NaCl}$ and the particulates in the flue gas. The XRD analysis and SEM images of the primary quenching tower ash matched the metal composition $(\mathrm{Na}=$ $202,000 \mathrm{mg} \mathrm{kg}^{-1}$ and $\mathrm{Cl}=312,000 \mathrm{mg} \mathrm{kg}^{-1}$ ).

Similar to the primary quenching tower ash, the structure of the sludge was also powdery and porous, and the crystalline phases were also $\mathrm{NaCl}$, with some $\mathrm{Na}_{4}\left(\mathrm{SO}_{4}\right)_{2} \cdot \mathrm{NaCl} \cdot \mathrm{NaF}$. However, the sludge had some flat, bulky structures that might have been due to using the frame filter for dewatering compression. Except for the crystalline phases of $\mathrm{NaCl}$ and $\mathrm{Na}_{4}\left(\mathrm{SO}_{4}\right)_{2} \cdot \mathrm{NaCl} \cdot \mathrm{NaF}$, the fabric filter ash still had another crystalline phase, $\mathrm{Na}_{20}\left(\mathrm{SO}_{4}\right)_{10} \cdot \mathrm{ZnCl}_{2} \cdot \mathrm{NaCl}$ (D'Ansite [Zn]), which also came from the neutralization of $\mathrm{NaOH}$ with acid pollutants. The fabric filter ash was powdery and porous, and its appearance matched the profile of crystalline phases.

\section{Comparison of the Old and Renovated Incineration Systems}

Table 4 shows a comparison of the renovated incineration system and the old one. Due to the injection of waste solvent to generate the local high-temperature environment, the $\mathrm{PCDD} / \mathrm{F}$ emission factor in this system was slightly reduced from 888 to $699 \mu \mathrm{g}$ I-TEQ ton-waste ${ }^{-1}$. In addition, the $\mathrm{PCDD} / \mathrm{F}$ concentration in the flue gas was greatly reduced from 0.491 to $0.109 \mathrm{ng}$ I-TEQ $\mathrm{Nm}^{-3}$. This contributed to the good performance of the renovated APCDs. In the old system, the PCDD/F masses (all were approximately 30\%) were roughly equally distributed in the bottom ash, primary quenching tower ash, and fabric filter ash. In the renovated incineration system, the $\mathrm{PCDD} / \mathrm{F}$ mass fraction in the primary quenching tower ash was only $1.66 \%$, but that in the scrubbing units (sludge and scrubbing wastewater) was as high as $97.02 \%$. The PCDD/Fs mainly existed as the particulate phase, so the sludge accounted for $92.97 \%$ of the $\mathrm{PCDD} / \mathrm{F}$ mass.

The emitted concentration of $\mathrm{HCl}$ in both incineration systems was lower than $1 \mathrm{ppm}$, and both systems relied on scrubbers to wash $\mathrm{HCl}$ out of the flue gas. However, in the old incineration system, the wet scrubber was set up after the fabric filter and could not prevent the fabric filter from being corroded. By contrast, the new design positioned the scrubbing units in front of the fabric filter, thus providing excellent protection for the fabric filter.

\section{CONCLUSIONS}

This study investigated the performance of a state-of-theart air pollution control system. The integration of waste solvent into the primary combustion chamber improved the combustion efficiency to $99.97 \%$ and also reduced the formation of PCDD/Fs. The APCDs effectively reduced the pollutive flue
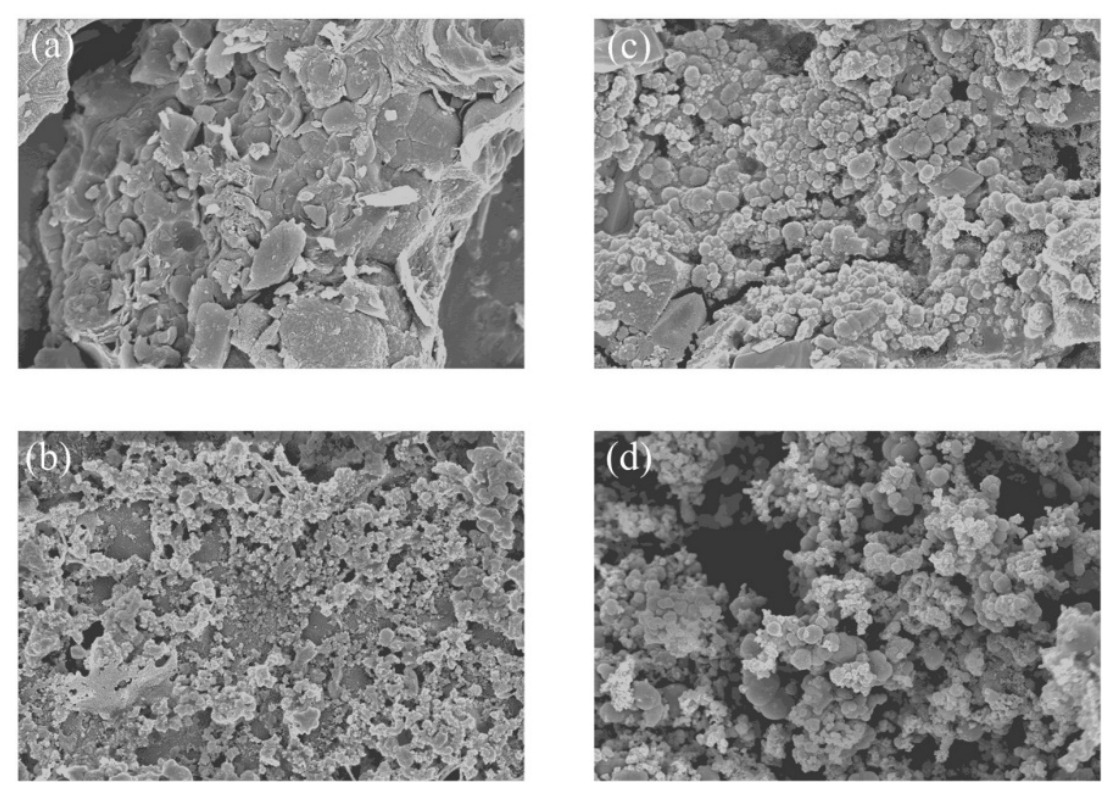

Fig. 4. SEM images of the solid specimens: (a) slag, (b) primary quenching tower ash, (c) sludge, (d) fabric filter ash. 


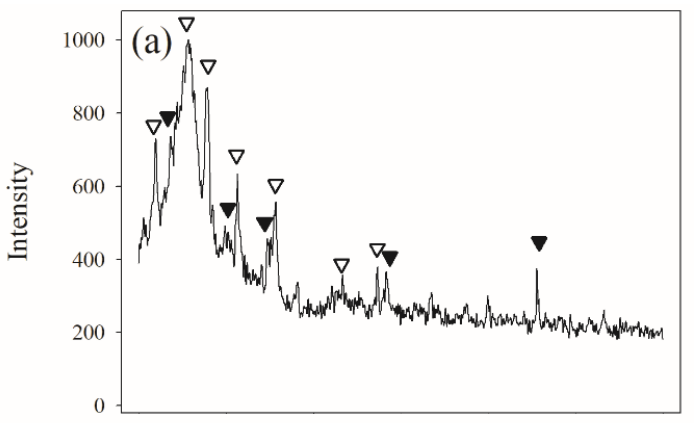

- $\mathrm{Ca}_{5}\left(\mathrm{SiO}_{4}\right)_{2}\left(\mathrm{SO}_{4}\right)$

$\nabla \mathrm{Ca}_{10}\left(\mathrm{SiO}_{4}\right)_{3}\left(\mathrm{SO}_{4}\right)_{3}(\mathrm{OH}, \mathrm{F}, \mathrm{Cl})_{2}$

- $\mathrm{Na}_{4}\left(\mathrm{SO}_{4}\right)_{2} \cdot \mathrm{NaCl} \cdot \mathrm{NaF}$

- $\mathrm{NaCl}$

- $4 \mathrm{Na}_{2}\left(\mathrm{SO}_{4}\right)_{2} \cdot \mathrm{H}_{2} \mathrm{O}_{2} \cdot \mathrm{NaCl}$
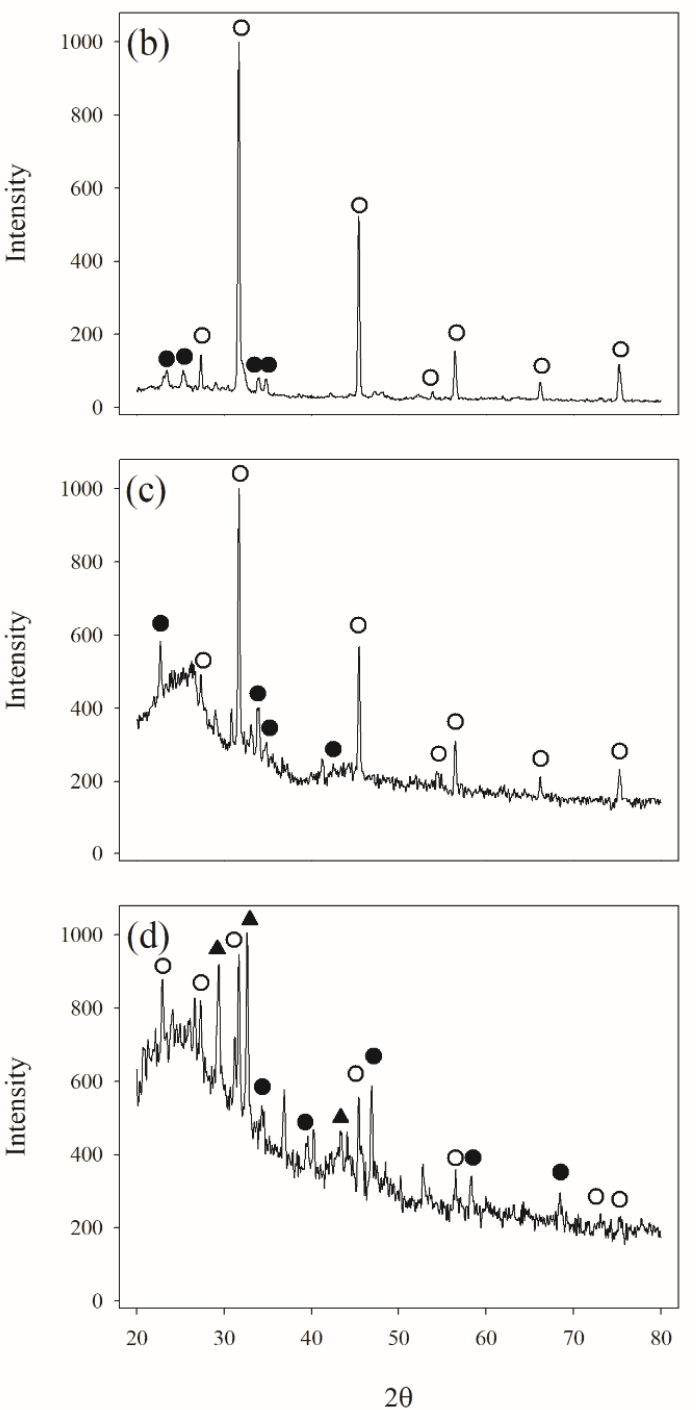

Fig. 5. XRD patterns of the output materials: (a) slag, (b) primary quenching tower ash, (c) sludge, (d) fabric filter ash.

Table 4. Comparison of the performance of the old and renovated incineration systems.

\begin{tabular}{lll}
\hline Item & Old system & Renovated system \\
\hline PCDD/F emission factor $(\mu \mathrm{g}$ ton-waste & -1 \\
PCDD/F concentration of flue gas $\left(\mathrm{ng} \mathrm{I}^{-T E Q ~ N m}{ }^{-3}\right)$ & 888 & 699 \\
Output materials where PCDD/Fs were mostly concentrated & 0.491 & 0.109 \\
& Secondary quenching tower & Recirculation water tank \\
& ash & sludge \\
$\mathrm{HCl}$ removal efficiency of APCDs & Excellent & Excellent \\
Main unit to remove HCl & Wet scrubber & Venturi/scrubbing tower \\
Protection of fabric filter & Poor & Excellent \\
\hline
\end{tabular}


gas emissions, resulting in concentrations significantly below the regulated standard. The primary component of the fly ash was $\mathrm{NaCl}$ or other sodium salts, which were formed when acidic pollutants neutralized the $\mathrm{NaOH}$. The $\mathrm{HCl}$ and PCDD/Fs were distributed mainly in the scrubbing wastewater and the sludge, respectively. The scrubbing unit provided excellent protection for the fabric filter by removing most of the $\mathrm{HCl}$ before the sample passed through the filter.

\section{REFERENCES}

Aurell, J. and Marklund, S. (2009). Effects of varying combustion conditions on $\mathrm{PCDD} / \mathrm{F}$ emissions and formation during MSW incineration. Chemosphere 75: 667-673.

Chang, C.P., Shen, Y.H., Chou, I.C., Wang, Y.F., Kuo, Y.M. and Chang, J.E. (2012). Metal distribution characteristics in a laboratory waste incinerator. Aerosol Air Qual. Res. 12: 422-430.

Chen, S., Cui, K., Zhao, Y., Yin, Z., Chao, H.R. and ChangChien, G.P. (2018). Sensitivity analysis of atmospheric $\mathrm{PM}_{2.5}$-bound content and dry deposition of total PCDD/Fs-TEQ: In the case of Xiamen and Zhangzhou, China. Aerosol Air Qual. Res. 18: 3096-3114.

Coutinho, M., Pereira, M., Rodrigues, R. and Borrego, C. (2006). Impact of medical waste incineration in the atmospheric PCDD/F levels of Porto, Portugal. Sci. Total Environ. 362: 157-165.

Fang, M.L., Chou, M.S., Chang, C.Y., Chang, H.Y., Chen, C.H., Lin, S.L. and Hsieh, Y.K. (2019). Chemical adsorption of nitrogen dioxide with an activated carbon adsorption system. Aerosol Air Qual. Res. 19: 2568-2575.

Hatanaka, T., Kitajima, A. and Takeuchi, M. (2005). Role of chlorine in combustion field in formation of polychlorinated dibenzo- $p$-dioxins and dibenzofurans during waste incineration. Environ. Sci. Technol. 39: 9452-9456.

Hsieh, Y.K., Chen, W.S., Zhu, J., Wu, Y.J. and Huang, Q. (2018). Health risk assessment and correlation analysis on PCDD/Fs in the fly ash from a municipal solid waste incineration plant. Aerosol Air Qual. Res. 18: 734-748.

Hung, N.T., Ting, H.W. and Chi, K.H. (2018). Evaluation of the relative health risk impact of atmospheric PCDD/Fs in $\mathrm{PM}_{2.5}$ in Taiwan. Aerosol Air Qual. Res. 18: 2591-2599.

Kuo, Y.M., Chang, J.E., Chang, K.Y., Chao, C.C., Tuan, Y.J. and Chang-Chien, G.P. (2010). Stabilization of residues obtained from the treatment of laboratory waste. Part 1: Treatment path of metals in a plasma melting system. J. Air Waste Manage. Assoc. 60: 429-438.

Kuo, Y.M., Lin, T.C. and Tsai, P.J. (2003). Effect of $\mathrm{SiO}_{2}$ on immobilization of metals and encapsulation of a glass network in slag. J. Air Waste Manage. Assoc. 53: 14121416.

Kuo, Y.M., Lin, T.C. and Tsai, P.J. (2004). Metal behavior during vitrification of incinerator ash in a coke bed furnace. J. Hazard. Mater. B109: 79-84.

Kuo, Y.M., Tseng, H.J., Chang, J.E., Wang, C.T., Wang, J.W. and Chang-Chien, G.P. (2011). Stabilization of residues obtained from the treatment of laboratory waste.
Part 2: A molding technology for reusing plasma vitrified slag. J. Air Waste Manage. Assoc. 61: 78-84.

Kuo, Y.M., Wang, Y.K., Lin, S.L., Yin, L.T. and Hsieh, Y.K. (2019). Air pollution characteristics of reclamation of refuse derived fuel (RDF) recovered from cutting oil waste. Aerosol Air Qual. Res. 19: 2576-2584.

Lee, W.S., Chang-Chien, G.P., Chen, S.J., Wang, L.C., Lee, W.J. and Wang, Y.H. (2004). Removal of polychlorinated dibenzo- $p$-dioxins and dibenzofurans in flue gases by Venturi scrubber and bag filter. Aerosol Air Qual. Res. 4: 24-34.

Liao, W.T., Wang, Y.F., Tsai, C.H., Tsai, Y.I, Wu, Z.L. and Kuo Y.M. (2014). Polychlorinated dibenzo- $p$-dioxin and dibenzofuran $(\mathrm{PCDD} / \mathrm{F})$ emission behavior during incineration of laboratory wastes. Part 2: PCDD/F profiles and characteristics of output materials. Aerosol Air Qual. Res. 14: 1206-1214.

Lin, Y.S., Chen, K.S., Lin, Y.C., Hung, C.H. and ChangChien, G.P. (2008). Polychlorinated dibenzo- $p$ dioxins/dibenzofurans distributions in ash from different units in a municipal solid waste incinerator. J. Hazard. Mater. 154: 954-962.

Liu, J., Zhang, J., Zhan, C., Liu, H., Zhang, L., Hu, T., Xing, X. and Qu, C. (2019a). Polycyclic aromatic hydrocarbons (PAHs) in urban street dust of Huanggang, central China: Status, sources and human health risk assessment. Aerosol Air Qual. Res. 19: 221-233.

Liu, S., Ji, P., Ye, D., Qu, R., Zheng, C. and Gao, X. (2019b). Regeneration of potassium poisoned catalysts for the selective catalytic reduction of $\mathrm{NO}$ with $\mathrm{NH}_{3}$. Aerosol Air Qual. Res. 19: 649-656.

Taiwan Environmental Protection Administration (TEPA) (2003). PCDD/F Emission Regulated Standards for Waste Incinerator: Atmospheric Pollution/Air Pollution. Taiwan Environmental Protection Administration, Taiwan.

Taiwan Environmental Protection Administration (TEPA) (2004). Standard Method for Analyzing Heavy Metals in Extracts from Industrial Waste Acid Digestion with Microwave. NIEA R317.11C. Taiwan Environmental Protection Administration, Taiwan.

Taiwan Environmental Protection Administration (TEPA) (2005). Determination of Particulate Concentrations from Stacks. NIEA A101.75C. Taiwan Environmental Protection Administration, Taiwan.

Taiwan Environmental Protection Administration (TEPA) (2006a). Determination of Nitrogen Oxides Concentrations from Stacks - Instrumental Analyzer. NIEA A411.75. Taiwan Environmental Protection Administration, Taiwan.

Taiwan Environmental Protection Administration (TEPA) (2006b). Determination of Sulfur Dioxides Concentrations from Stacks - Nondispersive Infrared. NIEA A413.75. Taiwan Environmental Protection Administration, Taiwan.

Taiwan Environmental Protection Administration (TEPA) (2006c). Determination of Carbon Monoxide Concentrations from Stacks - Nondispersive Infrared. NIEA A704.05. Taiwan Environmental Protection Administration, Taiwan.

Taiwan Environmental Protection Administration (TEPA) (2006d). Determination of Oxygen Concentrations from 
Stacks - Instrumental Analyzer. NIEA A432.74. Taiwan Environmental Protection Administration, Taiwan.

Taiwan Environmental Protection Administration (TEPA) (2006e). Determination of Heavy Metals Concentrations from Stacks. NIEA A302.73C. Taiwan Environmental Protection Administration, Taiwan.

Taiwan Environmental Protection Administration (TEPA) (2006f). Emission Regulated Standards of Air pollutants for Incinerator: Atmospheric Pollution/ Air Pollution. Taiwan Environmental Protection Administration, Taiwan.

Taiwan Environmental Protection Administration (TEPA) (2008). Determination of Hydrogen Chloride Concentrations from Stacks - Colorimetric Method, Mercury(II) Thiocyanate. NIEA A412.73A. Taiwan Environmental Protection Administration, Taiwan.

Taiwan Environmental Protection Administration (TEPA) (2010). Sampling Procedure of Polychlorinated Dibenzop-dioxins (PCDD), Polychlorinated Dibenzofuran (PCDF), and Polychlorinated Biphenyls Emissions from Stacks. NIEA A807.75C. Taiwan Environmental Protection Administration, Taiwan.

Taiwan Environmental Protection Administration (TEPA) (2013). Method for the Analysis of Polychlorinated Dibenzo- $p$-Dioxins (PCDDs), Polychlorinated Dibenzofurans (PCDFs) Emissions from Stacks. NIEA A808.75B. Taiwan Environmental Protection Administration, Taiwan.

Taiwan Environmental Protection Administration (TEPA) (2016). Determination of Carbon Dioxides Concentrations from Stack - Nondispersive Infrared. NIEA A415.73A. Taiwan Environmental Protection Administration, Taiwan.
Tsai, J.H., Chen, S.J., Li, P.M., Chang-Chien, G.P., Huang, K.L., Tsai, C.H., Hsieh, C.Y. and Lin, C.C. (2018). Characteristics of $\mathrm{PM}_{2.5}$-bound PCDD/Fs, PCBs, $\mathrm{PBDD} / \mathrm{Fs}$ and PBDEs from a diesel generator using waste cooking oil-based biodiesel blends. Aerosol Air Qual. Res. 18: 2583-2590.

Wang, L.C. and Chang-Chien, G.P. (2007). Characterizing the emissions of polybrominated dibenzo- $p$-dioxins and dibenzofurans from municipal and industrial waste incinerators. Environ. Sci. Technol. 41: 1159-1165.

Wang, L.C., His, H.C., Wang, Y.F., Lin, S.L. and ChangChien, G.P. (2010). Distribution of polybrominated diphenyl ethers (PBDEs) and polybrominated dibenzo- $p$ dioxins and dibenzofurans (PBDD/Fs) in municipal solid waste incinerators. Environ. Pollut. 158:1595-1602.

Wu, J.L., Lin, T.C., Wang, L.C. and Chang-Chien, G.P. (2014a). Memory effects of polychlorinated dibenzo- $p$ dioxin and furan emissions in a laboratory waste incinerator. Aerosol Air Qual. Res. 14: 1168-1178.

Wu, J.L., Lin, T.C., Wang, Y.F., Wang, J.W., Wang, C.T. and Kuo, Y.M. (2014b). Polychlorinated dibenzo-pdioxin and dibenzofuran (PCDD/F) emission behavior during incineration of laboratory waste. Part 1: Emission profiles obtained using chemical assay and bioassay. Aerosol Air Qual. Res. 14: 1199-1205.

Received for review, February 28, 2020 Revised, March 30, 2020 Accepted, April 4, 2020 